\title{
Átmenet a kolozsvári felsőoktatásból az IT szektorba ${ }^{1}$
}

\author{
SZÉKELY KINGA ${ }^{2}$
}

\begin{abstract}
ABSZTRAKT
Jelen tanulmányban arra a kutatási kérdésre keressük a választ, hogy milyen tényezők befolyásolják az átmenetet a felsőoktatásból az IT piacra az informatikát, számítástechnikát és automatizálás szakot végzettek esetében Kolozsváron? A kutatási eredmények azt mutatják, hogy a Kolozsvári IT piac helyzete meghatározza a frissen végzettek átmenetét, melyet egyrészt a nyugati piactól való függőség, másrészt a munkaerőért folytatott verseny jellemez. Az előbbi tényezőt fenntartja a hiányszakmák jelensége Kolozsváron. A függési viszony csökkentésére a megoldást az IT-vel határos szakterületeken új képzések elindításában látják az egyetemi oktatók. Az utóbbi tényező (a munkaeröért folytatott verseny) következtében az átmenet gördülékeny a frissen végzettek számára. A fiatalok elhelyezkedése során azonban kiválasztási szempontot jelent, hogy a frissen végzett szakmában, megfelelő munkakörben, munkakörnyezetben dolgozzon és/vagy megfelelő juttatás mellett. A munkaerôhiány kezelésére - mely egyidejüleg van jelen az IT piacon és a felsőoktatásban -, a megoldást az oktatás minőségének és az átmenetet elösegítő programok biztosítása mellett (mint a szakmai gyakorlatok és a mentorprogram), az akadémiai karrier vonzóvá tételében látják az egyetemi oktatók hosszú távon. Ezt a megoldást a vállalatok, az állam és a felsőoktatás szoros együttmúködésében látják megvalósíthatónak a megkérdezettek az oktatói létszám, a kutatástámogatás és az infrastruktúra biztosítása révén.
\end{abstract}

KULCSSZAVAK: IT szektor, foglalkoztatás, átmenet, felsőoktatás, frissen végzettek

\section{ABSTRACT}

\section{Transition from higher education to the IT sector in Cluj-Napoca}

The present paper focuses on those factors that affect transition from higher education to the IT sector in Cluj-Napoca, in cases of entrants with informatics, automatization and computer technology degree. The results show that transition to the IT market in Cluj-Napoca is primarily influenced by the dependency of the local IT market on western IT markets with more central positions, followed by the competition for workforce. The first factor: dependency is due to skill shortages on the labour market in Cluj-Napoca. Launching new trainings with the involvement of other departments at universities, such as design, business, sales, marketing or business informatics can reduce dependency according to the representatives of the local institutions

\footnotetext{
${ }^{1}$ A tanulmány alapjául szolgáló kutatás megvalósulását a Rézler Gyula Alapítvány támogatta.

${ }^{2}$ Doktorjelölt, Budapesti Corvinus Egyetem, Szociológia Doktori Iskola.
} 


\section{TEMATIKUS TANULMÁNYOK - A munkaerőpiac gazdasági-társadalmi kérdései}

of higher education. Transition from higher education to the IT sector for entrants in ClujNapoca is smooth, due to the strong competition for workforce (second factor). Entrants select their potential workplace based on the reputation of a workplace, position/projects, team and remuneration. Labour shortage is present both in the IT sector and in higher education. A long-term solution for reducing labour shortage in both sectors could be provided by creating attractive career paths in the academy which would require stronger cooperation between companies, state and higher education institutions, according to the representatives of the institutions of higher education.

KEYWORDS: IT sector, employment, transition, higher education, entrants

\section{Bevezetés}

Jelen tanulmányban arra a kutatási kérdésre keressük a választ, hogy milyen tényezők befolyásolják az átmenetet a felsőoktatásból az IT piacra az informatikát, számítástechnikát és automatizálás szakot végzettek esetében Kolozsváron? A kérdés megválaszolása érdekében megvizsgáljuk, hogy milyen kihívásokkal néznek szembe a piaci szereplők és a felsőoktatási intézmények, valamint, hogy milyen megoldási javaslatokat fogalmaznak meg, keresve a keresztmetszetet a megvalósulás érdekében. A tanulmány során a felsőoktatási intézmények perspektíváján keresztül kívánom megvizsgálni a frissen végzettek elhelyezkedésével kapcsolatos kérdéseket, kitérve a felsőoktatás és piac közötti együttműködésekre is. A tanulmányban használt definíció szerint az IT piac magába foglalja mindazon tevékenységeket és szereplőket, amelyek részt vesznek egy IT termék termelési folyamatában, a termékleírástól, a támogató szolgáltatások (service support) biztosításáig, és saját termékfejlesztés esetén a hozzá kapcsolódó marketing tevékenységet is magába foglalja (Kiss - Péter 2018).

A kutatás során alkalmazott módszerek között megtalálhatók a kvantitatív és kvalitatív módszerek egyaránt. A kvantitatív módszerek közül a másodelemzés módszerével dolgoztam a román Nemzeti Statisztikai Hivatal statisztikai adatain (felhasználva a Tempo-Online adatbázis, az eDemos, a népszámlálási adatok, és az AMIGO háztartási munkaerő-felmérés adatait). A tartalomelemzés módszerével a romániai IT piacra vonatkozó foglalkoztatáspolitikai törvényi keretet és gyakorlatokat vizsgáltam meg. A félig strukturált személyes interjúk képezik a kvalitatív kutatás alapját. Két interjú kerül feldolgozásra jelen tanulmány keretén belül, Kolozsváron a két legnagyobb állami felsőoktatási intézmény képviselője, ahol IT szakemberek képzése zajlik, a képzés által nyújtott lehetőségekről és kihívásokról számolt be. 


\section{TEMATIKUS TANULMÁNYOK - A munkaerőpiac gazdasági-társadalmi kérdései}

\section{Elméleti keretrendszer}

A tanulmányban bemutatott elméletek keretrendszerként szolgálnak, segítségünkre vannak abban, hogy keretbe helyezzük a globális és helyi IT piac összefüggéseit, az IT ágazat belső munkaerőpiaci szerkezetének alakulását és a vizsgált piaci szereplők döntései mögött álló mozgatórugókat.

A világrendszer elmélet (World-System Approach) (Wallerstein 2010) szerint a világ gazdasága szegmentált, ahol központi és periférikus területek vannak jelen. A központi területek között megtaláljuk a fejlett országokat, míg a periférikus területek azok, amelyek kiszolgálják a központi területeket. A globalizáció ${ }^{3}$ révén a különböző régiók, országok, uniók gazdaságai szorosan összekapcsolódnak egymással, amelyek között kölcsönös függőség alakul ki. A kialakult függőség nem szimmetrikus viszonyokban ölt testet. Egy adott országon belül is megfigyelhető lehet a szegmentáltság, a központi és periférikus régiók között lényeges eltérések lehetnek.

A duális (szegmentált) munkaerőpiac elmélet szerint szegmentált munkaerőpiac esetén az iparilag fejlett országok számára elsődleges a hazai munkaerő számára hozzáférhető, jó jövedelmet biztosító, legális és felülszegmentált munkaerőpiac, míg másodlagos a szintén legális, de alacsony presztízst és jövedelmet kínáló alulszegmentált munkaerőpiac (Póczik - Dunavölgyi 2008). Az elmélet kiindulópontja, hogy a technológiai fejlődés következtében eltávolodnak egymástól a specifikus készségeket és az általános készségeket igénylő munkahelyek. Míg az első típusú munkahely betöltése kívánatos a helyiek és/vagy szakmabeliek számára, addig a második típusú nem kívánatossá válik, aminek következtében máshonnan és/vagy más szakterületről érkezik a munkaerő a feladatok elvégzésére. Az elmélet szerint a munkaerőhiányra a megoldást a földrajzi helyváltoztatás (migráció) jelenti. A globalizáció egy másik alternatívát (is) kínál. A globalizációnak, a világméretűvé vált termelési lehetőségeknek köszönhetően a termékek előállítása és a szolgáltatások előállítása elvándorol ${ }^{4}$ oda, ahol olcsó és jó minőségű a munkaerő. A tranzakciós költség elméletet hívtuk segítségül, annak érdekében, hogy megértsük a vállalatok milyen gazdasági cselekvési forma mellett döntenek egy ilyen helyzetben. A vállalati döntés fontos, mivel munkalehetőségek teremtésében testesülnek meg, amelyek eltérő karrierutakat kínálnak a munkavállalóknak. A szegmentált munkaerőpiac elmélettel szemben a tranzakciós költség elmélet esetében nem a munkaerő, hanem a munka vándorol. A vállalatok a globális piacon két megoldás közül választhatnak, egyrészt az adott vállalat maga állítja elő az adott terméket vagy szolgáltatást, vagy a tevékenysége(ke)t kiszervezik (egy távoli országba). A kiszervezés (outsourcing) fogalmának lé-

\footnotetext{
${ }^{3}$ „Az a folyamat, amelynek következtében a különböző országok, uniók gazdaságai egymással szorosan összekapcsolódnak, ami lehetővé teszi a termékek, a szolgáltatások, a tőke, a munkaerő szabad áramlását." (Sebők 2018: 391).

${ }^{4} \mathrm{~A}$ tőke és munkaerő szabad áramlása mellett lehetővé vált a termékek és szolgáltatások szabad áramlása is (Szentes 2000).
} 


\section{TEMATIKUS TANULMÁNYOK - A munkaerőpiac gazdasági-társadalmi kérdései}

tezik egy szúkebb és egy tágabb definíciója. Szabó Katalin a kiszervezés szűkebb definícióját használja, amelyet a következőképpen fogalmaz meg: a vállalaton belül már meglévő feladatok, funkciók kihelyezése és ezzel egyidejűleg a hozzájuk tartozó eszközök, berendezések, illetve kapacitások kihelyezése, külső szolgáltatókra bízása (Szabó 1995). Rávilágít a tágabb értelmezésére is a fogalomnak, amelyhez hozzátartoznak a vállalat számára szükséges részegységek, részfeladatok ${ }^{5}$, funkciók külsősökkel való elvégeztetése, a berendezések, erőforrások egyidejű kihelyezése nélkül (contracting out) (Szabó 1995), a munkaerő-állomány kívülről történő kölcsönzése (bodyleasing) (Szabó 1995), melyet ma már kiegészít a teljes projekt folyamat kiszervezése. Jelen tanulmányban a kiszervezés (outsourcing) tág definícióját használjuk, amely egybeesik az interjúalanyok által használt értelmezéssel, amely magába foglalja a teljes projekt folyamat-, valamint a részfeladatok kiszervezését, és a munkaerő-kölcsönzést is. A tranzakciós költség elmélet szerint a kiszervezés melletti döntést elsődlegesen a költségcsökkentés motiválja. Ha kevesebbe kerül egy termék vagy szolgáltatás elóállítása, amennyiben nem saját maguk állítják elő, úgy kiszervezésre kerül. A kiszervezéssel azonban nemcsak a munka helyeződik át új környezetbe, de a piac szegmentálódásának problémája is. A szegmentálódás megjelenhet nemzeti, regionális vagy lokális szinten. Felmerül a kérdés, hogy a tanulmány tárgyát képező IT piac szegmentált, illetve a szegmentáltság milyen szinteken jelenik meg (lokális, regionális, nemzeti, globális)?

Szabó (1995) rávilágít arra, hogy a kiszervezést a versennyel összefüggésben szükséges tárgyalni, ahol a kiszervezett tevékenységet végzőket (outsourcer-eket) a költségcsökkentés szempontja mellett a minőségi eredményeik alapján is lemérik. A piaci versenynek köszönhetően a munkaerőpiac átrendeződik, és a „korábbi kínálatalapú ${ }^{6}$ piacot felváltja a kereslet ${ }^{7}$ orientált munkaerőpiac" (Sebők 2018: 290), ahol a piacon a munkaerővel kapcsolatos elvárások is megváltoznak, és az egyéni készségek kerülnek előtérbe (softskills), amely mellett hangsúlyosan jelen van az elvárások között az egész életen át tartó tanulásra ${ }^{8}$ (Life Long Learning - LLL) való nyitottság (Sebők 2018).

\footnotetext{
${ }^{5}$ A nagyvállalatok termeléséből egyre nagyobb részt vállalnak át a beszállítók (Szabó 1995).

${ }^{6}$ Munkaerő-kínálat: „az adott időszakban rendelkezésre álló munkanélküliek és álláskeresők számát és összetételét jeleníti meg." (Sebők 2018: 210)

${ }^{7}$ Munkaerő-kereslet: „a munkáltatók által megjelenített azon igény, hogy egy meghatározott időszakban milyen létszámú és összetétel munkaerőt kívánnak foglalkoztatni.” (Sebők 2018: 210)

${ }^{8}$ Az egész életen át tartó tanulás (Life Long Learning) magába foglal minden formális, nem formális és informális tanulást az Európai Bizottság megfogalmazásában (Sebők 2018).
} 


\section{TEMATIKUS TANULMÁNYOK - A munkaerőpiac gazdasági-társadalmi kérdései}

\section{Az IT piac bemutatása az állami reguláció és statisztikai adatok fényében}

\section{1. ÁLLAMI REGULÁCIÓ ÉS AZ IT ÁGAZATRA VONATKOZÓ FOGLALKOZÁSPOLITIKAI GYAKORLATOK}

A román állam az IT cégek részére, olyan aktív munkaerőpiaci eszközöket dolgozott ki, amelyek a munkahelyteremtést szolgálják, és/vagy a foglalkozáshoz köthető járulékok terhe alól mentesítenek. Az első eszköz révén a Pénzügyi Minisztérium nagyvállalatok támogatását tűzte ki célul ${ }^{9}$, annak érdekében, hogy a külföldi befektetők elköltözését megelőzzék (olyan országokba, ahol olcsóbb a munkaerő költsége). 2016-ban, 11 külföldi tőkéjű cég részesül a román állam támogatásában országos szinten, annak érdekében, hogy 4000 új munkahelyet ${ }^{10}$ hozzanak létre, melyet öt évig fenntartanak. A támogatásokat állami és Európai Uniós forrásokból biztosítják. A támogatási formák között megjelenik a munkavállalókkal járó költségek résztámogatása (50\%) kétéves időtartamra vonatkozóan. A második eszköz révén, a román állam a programozókat mentesíti a személyi jövedelemadó megfizetése alól ${ }^{11}$ (SZJA), mely a vizsgálat időpontjában 16\% volt, és amely 2018. január 1-től 10\% lett a Nemzeti Pénzügyi Intézet (Agentia Nationala de Administrare Fiscala) weboldalán elérhető 79/2017. számú sürgősségi kormányrendelet szerint (Románia Kormánya - Guvernul Romaniei 2017), mely a 227/2015. számú törvény módosításait és kiegészítését tartalmazza, és amely 2018. január elsején lépett hatályba. Ez a jövedelemadó-kedvezmény az Európai Unió területén csak Romániában hatályos és azon cégek alkalmazhatják, melyek éves bevétele meghaladta a 10000 amerikai dollárnak megfelelő értéket az előző évben. Az adókedvezmény vonzerővel bír a nagy- és külföldi vállalatok esetében, elősegíti a munkaadók helyben maradását. A kedvezményekkel a mikro-, és kisvállalkozások nem, vagy csak korlátozott mértékben tudnak élni, amennyiben teljesítik az éves üzleti forgalomra vonatkozó feltételt. A román állam országos ágazati foglalkoztatáspolitikája a nagy- és közepes vállalatoknak kedvez elsősorban.

A román állam további aktív munkaerőpiaci eszközöket is alkalmaz a munkaadók és munkavállalók esetében, amelyek nem ágazatspecifikusak. A munkaadóknak nyújtott aktív munkaerőpiaci eszközök között megtalálhatók a bértámogatások

\footnotetext{
${ }^{9}$ Lásd a 797/2012 sz. Kormány Határozatot. Románul: Hotararea Guvernului Nr. 797/2012.

${ }^{10}$ A digi24.ro hírportál cikke: a román állam fedezi az IT ágazatban dolgozók fizetését. Egy jászvásári (Iasi) IT vállalat 5,4 millió euro támogatást kap az államtól új pozíciók létrehozására Stefan Rusu, a vállalat menedzsere szerint. Elmondása szerint a létrehozott munkahelyi pozíciók a pályakezdőtől (entrylevel) kezdődnek, a junior, az experience-en keresztül, a senior, a mérnök (arhitect) és menedzsment pozíciókra is kiterjednek. A cikk román nyelvű címe: Salariile angajaților IT, plătite de stat. O companie din Iași va primi 5,4 milioane de euro de la buget;

${ }^{11}$ Lásd a 217/4172/1348/835/2015 sz. rendeletet.
} 


\section{TEMATIKUS TANULMÁNYOK - A munkaerőpiac gazdasági-társadalmi kérdései}

és a képzési programok támogatása, például a frissen végzett ${ }^{12}$ munkavállalók ${ }^{13}$ esetében a tanonc- és gyakornoki program révén. A tanonc- és gyakornoki program a frissen végzett számára egyszerre jelent szakmai és munkatapasztalatot hat hónapos időtartamra (más rendelkezés esetén az időtartam eltérő lehet), ugyanakkor a készségeinek és képességeinek fejlesztését a munkaerőpiacon, mentor vezetése, ellenőrzése és anyagi juttatás biztosítása mellett.

Az Európai Bizottság által kidolgozott „Ifjúsági Garancia” ${ }^{14}$ nevű intézkedéscsomagot (Youth Guarantee ${ }^{15}$ ) Románia ${ }^{16}$ is alkalmazza, annak érdekében, hogy a fiatalokat bevonja a foglalkoztatásba. Romániában a Garantia pentru Tinere ${ }^{17}$ nevet viseli a program, amely 2014/2015-ben indult útjára. Az intézkedéscsomag a 25 év alatti fiatalokat célozta meg (16-24 éves korosztály), akik sem a foglalkoztatásban, sem az oktatásban vagy képzésben nem vesznek részt (ún. NEET) ${ }^{18}$. A fiatalok számára a következő aktív munkaerőpiaci eszközöket és szolgáltatásokat foglalja magába: gyakornoki programok, fiatalok vállalkozóvá válásának támogatása, nonprofit szervezetek fiatalok foglalkoztatását segítő programjai. A romániai Ifjúsági Garancia program a munkaadók számára a következő támogatási lehetőségeket biztosítja: bér- és bérköltség-támogatás, valamint a munkavállaló képzési költségének támogatása, a romániai Munkaügyi és Szociális Igazságosság Minisztérium weboldalán közzétett sajtótájékoztató anyag szerint („Ifjúsági Garancia” a legkiterjedtebb program a fiatal munkanélküliség visszaszorítására az elmúlt 25 évben 2015).

\subsection{A ROMÁNIAI IT PIAC MÜKÖDÉSE}

Az IT piac a román gazdaság egyik fontos motorja, melyet a következő mutatók segítségével kívánok bemutatni: foglalkoztatottak száma az ágazaton belül, az IT cégek éves üzleti forgalma, az ágazat bruttó hazai össztermékhez (GDP) való hozzájárulása, valamint ezen mutatók kapcsán mutatkozó trendek (2012-2015/2017 között) a rendelkezésre álló adatok függvényében.

A román Nemzeti Statisztikai Hivatal Tempo-Online adatbázisa alapján az Információ és kommunikáció ágazatok (Informatii si comunicatii) együttesen (IT\&C) a teljes foglalkoztatott népességen belül (8,5 millió fó) 153 ezer főt $(1,8 \%)$ foglal-

\footnotetext{
${ }^{12}$ Szakterülettől függetlenül.

${ }^{13}$ Lásd a 335/2013-as törvényt (Legea 335/2013), amely a privát szférát célozza meg, a támogatásban közintézmények és közhivatalok nem részesülhetnek a 335/2013-as törvény 28. cikkely (6.) bekezdése szerint.

${ }^{14}$ Lásd a programot Magyarországon: http://ifjusagigarancia.gov.hu/

${ }^{15}$ Az Európai Bizottság által használt megnevezés. Forrás: http://ec.europa.eu/

16 Jelenleg a tagországok mindegyikében müködik.

${ }^{17}$ Lásd a programot Romániában: http://garantiapentrutineret.ro

${ }^{18}$ Az Ifjúsági Garancia program célja, hogy a fiatalok minél kevesebb időt töltsenek a munkanélküliségben és négy hónapon belül egy megfelelő munkaajánlatot, továbbtanulási lehetőséget, vagy tanonc/ gyakornoki idő eltöltésére vonatkozó lehetőséget kapjanak.
} 


\section{TEMATIKUS TANULMÁNYOK - A munkaerőpiac gazdasági-társadalmi kérdései}

koztattak 2012-ben. 2017-ben már ötvenezer fővel többen (205 ezer fó) dolgoztak ezekben az ágazatokban, ami a foglalkoztatott népesség (8,3 millió fó) 2,45\%-át jelentette a Tempo-Online adatbázis adatai szerint (Nemzeti Statisztikai Hivatal 2018). Az ARIES ${ }^{19}$ által létrehozott iTech Transilvania Cluster ${ }^{20} 2015$-ös éves kutatási ${ }^{21}$ eredményei szerint az IT cégek éves üzleti forgalma növekedést mutatott 2014-ben: 26\%-os volt a növekedés az előző évhez viszonyítva. Ekkor az IT cégek éves üzleti forgalma megközelítette a 4 milliárd eurót, 92 ezer fővel a 2015-ös ARIES kutatás eredményei szerint (Az IT ágazat Romániában: 14000 vállalattal, 75500 alkalmazottal és 4 milliárd euro bevétellel 2015).

Az IT \& C szektor 2016-ban 5,5\%-kal járult hozzá a GDP-hez a Friedrich-Ebert-Stiftung Romania a Monitorul Social (társadalomfigyelő) projekt keretén belül készült elemzés adatai szerint. Az IT szektor hozzájárulása a GDP értékéhez 2016-ban (a kommunikációs ágazat nélkül) 3\% volt (4,8 milliárd euro) az ARIES 2017 kutatás eredményei szerint (Az IT piac vizsgálata 2017). A román Nemzeti Statisztikai Hivatal Tempo-Online adatbázisában rendelkezésünkre álló adatok részben teszik lehetővé az ágazati összehasonlítást ${ }^{22}$. Az összehasonlító elemzésben az Információ és kommunikáció (IT\&C) ágazat és a pénzügyi szolgáltatás- és biztosításközvetító ágazat 2012. és 2015. évi adatait ${ }^{23}$ hasonlítjuk össze. Ez a két ágazat hasonlít leginkább egymáshoz a GDP hozzájárulás és foglalkoztatottak száma tekintetében. Az IT\&C ágazat hozzájárulása 2015-ben a bruttó hazai termékhez 35993 millió RON értékű volt (186 ezer foglalkoztatottal), amely 7963 millió eurónak ${ }^{24}$ felelt meg. A hozzájárulás értéke folyamatosan növekvő tendenciát mutat az előző évekhez viszonyítva (2012-2015 között): ez az érték 2012-ben még 5374 millió eurónak felelt meg25 (153 ezer fővel). A pénzügyi szolgáltatás- és biztosításközvetítő ágazat (Intermedieri

${ }^{19}$ ARIES - Asociatia Romana pentru Industria Electronicasi Software alapítvány, amely a romániai információ és kommunikáció ágazat hazai és külföldi érdekképviseletét látja el.

${ }^{20}$ Az iTech Transilvania Cluster nonprofit szakmai szerveződés (ezen belül: szakmai klaszter), amelynek célja az együttműködés elősegítése a tagok között, mely három pilléren áll: privát szféra (cégek), oktatás (egyetem) és önkormányzat (állami szféra); vagy a tagok és más intézmények/ vállalatok közötti együttműködést hivatott elősegíteni Romániában és az országon kívül, projektek révén. A tagok között megtalálhatók a gazdasági értelemben vett nagyvállalatok, a kis- és középvállalkozások, a felsőoktatási intézmények és kutatóközpontok is. A projektek jellege: innovációtámogatás, a munkavállalók képzése révén (technikai és softskill képzések), tudásbázis és tréner adatbázis kiépítése révén, a jelenleg futó projektek kapcsán.

${ }^{21}$ Az IT cégek 2014. évi jövedelemnyilatkozata alapján, valamint az ország legnagyobb ágazati munkaadóinak felmérése alapján, 393 fős minta alkalmazásával.

${ }^{22}$ Azon ágazatok adatait nem tudjuk használni, ahol egymástól jelentősen eltérő ágazatok adatai aggregálva szerepelnek, mint például a vendéglátóipar eredményeit hozzárendeli a kis- és nagykereskedelem és a gépjárművek és motorkerékpárok javítása során termelt értékhez.

${ }^{23}$ A frissebb, 2018-as adatok nem elérhetőek.

${ }^{24}$ A Román Nemzeti Bank (Banca Nationala Romana) 2015.12.31.-i árfolyamával számolva 1 euro $4,52 \mathrm{RON}$.

${ }^{25}$ A Román Nemzeti Bank (Banca Nationala Romana) 2012.12.31.-i árfolyamával számolva 1 euro 4,42 RON. 


\section{TEMATIKUS TANULMÁNYOK - A munkaerőpiac gazdasági-társadalmi kérdései}

financiare si asigurari) hozzájárulása 22997 millió RON volt a GDP értékéhez 2015ben (102 ezer foglalkoztatottal), amely 5087 millió eurót jelentett. A hozzájárulás mértéke hullámzó volt az ezt megelőző években (2012-2015 között), azonban növekedés figyelhető meg a 2012-es adatokhoz viszonyítva, mikor 4050 millió euro volt a hozzájárulás értéke (114 ezer alkalmazottal). A két ágazat egy foglalkoztatottra eső ${ }^{26}$ hozzájárulása 2012-ben hasonló nagyságrendű volt: IT \& C: 35124 euro/fö, pénzügyi szolgáltatás és biztosításközvetítés: 35526 euro/fö, a növekedés a pénzügyi szolgáltatás- és biztosításközvetítő ágazat esetében intenzívebb volt a 2015-ös adatok összehasonlításában: IT \& C: 42811 euro/fö, pénzügyi szolgáltatás és biztosításközvetítés: 49872 euro/fö.

Végül, az ágazaton belül a havi nettó átlagjövedelem értékét is vizsgáltuk az ARIES 2015 kutatása alapján, melyet 393 IT cég körében végzett. A nettó havi átlagjövedelem értéke a vizsgálat időpontjában (2015 közepén) 2600 RON, azaz 580 euro $^{27}$ volt (az IT ágazat Romániában: 14000 vállalattal, 75500 alkalmazottal és 4 milliárd euro bevétellel 2015). A 2014-es év végén az országos havi átlagjövedelem 1866 RON volt, ami 416 euro $^{28}$-nak felelt meg. Fontos megjegyezni, hogy az IT szektor átlagjövedelmét az ágazatban dolgozók együttesen alkották, ami azt jelenti, hogy az IT szakemberek mellett az adminisztratív, HR és egyéb személyzet fizetése is megjelent, melyek sok esetben alacsonyabbak az IT szakemberek fizetésénél.

Összefoglalva a statisztikai eredményeket azt mondhatjuk, hogy az IT\&C ágazatban foglalkoztatottak számának folyamatos növekedése és az éves üzleti forgalom növekedése pozitívan befolyásolta az ágazat GDP hozzájárulását is. Az IT\&C ágazat GDP hozzájárulása összességében nagyobb volt 2012-ben és 2015-ben is, mint a pénzügyi szolgáltatás- és biztosításközvetítő ágazat hozzájárulása. Az egy foglalkoztatottra jutó GDP hozzájárulás tekintetében a pénzügyi szolgáltatás- és biztosításközvetítő ágazatban 2012-ben valamivel magasabb, 2015-ben jelentős eltérés volt megfigyelhető a pénzügyi ágazat javára, ami az ágazat gyorsabb növekedését jelenti. A vizsgált periódusban (2012-2015 között) a pénzügyi szolgáltatás- és biztosításközvetítő ágazat hullámzó hozzájárulása rámutat arra, hogy kiszámíthatatlanabb ágazatról van szó, míg az IT\&C ágazat folyamatos növekedése nagyobb megbízhatóságot mutat. Az eredmények alapján azt látjuk, hogy az IT ágazat a román gazdaság fontos, de nem kizárólagos motorja a vizsgálat időpontjában.

\footnotetext{
${ }^{26}$ Az értéket úgy kapjuk meg, hogy a hozzájárulás értékét elosztjuk a foglalkoztatottak számával.

${ }^{27}$ A Román Nemzeti Bank (Banca Nationala Romana) 2014.12.31.-i árfolyamával számolva 1 euro $4,48 \mathrm{RON}$.

${ }^{28}$ A Román Nemzeti Bank (Banca Nationala Romana) 2014.12.31.-i árfolyamával számolva 1 euro - 4,48 RON.
} 


\section{TEMATIKUS TANULMÁNYOK - A munkaerőpiac gazdasági-társadalmi kérdései}

\subsection{FIATALOK AZ IT ÁGAZATBAN}

Az Információ és kommunikáció (IT\&C) ágazat növekedésében fontos szerepet játszanak a fiatalok (25-34 év közöttiek) a Nemzeti Statisztikai Hivatal adatai szerint, ugyanis a foglalkoztatottak 46\%-át a 25-34 év közötti korosztály alkotta 86 ezer fövel, 2017-ben. A 15-24 éves korosztály kisebb mértékben jelent meg (11 ezer fővel), azonban együtt az alkalmazottak 52\%-át alkották. Hasonlóképpen a fiatal korosztályra épített 2017-ben, a pénzügyi szolgáltatás- és biztosításközvetítő ágazat (Intermedieri financiare si asigurari), ahol a 25-34 éves korosztály az alkalmazottak 38\%át alkotta 44 ezer fővel, a 15-24 éves korosztály kisebb mértékben jelent meg (5 ezer fővel), összesen az alkalmazottak 43\%-át alkották. A gazdasághoz jelentős mértékben hozzájáruló vizsgált két ágazatnak fontos szereplői a fiatalok. A két ágazat sajátosságából adódóan jellemzően szellemi foglalkozást kínálnak, amelynek feltétele a felsőfokú képzéshez kapcsolódó kompetenciák, így a felsőfokú végzettséggel rendelkező fiatalok kerültek kutatásunk középpontjába.

\subsection{A KOLOZSVÁRI IT PIAC}

Romániában 2015-ben 13800 IT cég múködött, melynek 48\%-a Bukarestben és Kolozsváron volt az ARIES ${ }^{29}$ által létrehozott iTech Transilvania Cluster ${ }^{30}$ a 2015-ös év során készített ágazati (IT) kutatásának eredményei szerint (Az IT ágazat Romániában: 14000 vállalattal, 75500 alkalmazottal és 4 milliárd euro bevétellel 2015). 2016-ban a cégek száma elérte a 14 339-et az ARIES 2017-es kutatásának eredményei szerint (Tanulmány az IT piacról - Nemzeti összehasonlító vizsgálat 2017). A 2014-es adatok alapján az IT cégek teljes üzleti forgalmának (amely megközelítette a 4 milliárd eurót) 69\%-át Bukarest (58\%-ban) és Kolozsvár (11\%-ban) bonyolította, őket követte a többi megye (Az IT ágazat Romániában: 14000 vállalattal, 75500 alkalmazottal és 4 milliárd euro bevétellel 2015). Az ARIES kutatási eredményei alapján a foglalkoztatottak számát tekintve országos szinten az IT szektorban $92500^{31}$ fó volt elhelyezkedve 2014-ben, míg 2016-ban már több mint 100000 fó tartozott az ágazathoz (Tanulmány az IT piacról - Nemzeti összehasonlító vizsgálat 2017).

${ }^{29}$ ARIES - Asociatia Romana pentru Industria Electronicasi Software alapítvány, amely a román információ és kommunikáció ágazat hazai és külföldi érdekképviseletét látja el.

${ }^{30}$ Az iTech Transilvania Cluster nonprofit szakmai szerveződés (ezen belül: klaszter), amelynek célja az együttműködés elősegítése a tagok között (akik egyben piaci szereplők is), vagy a tagok és más intézmények és vállalatok közötti együttműködést hivatott elősegíteni Romániában és az országon kívül, projektek révén.

${ }^{31}$ Melyből 75500 fő alkalmazott és 17000 fő egyéni vállalkozó volt. 


\section{TEMATIKUS TANULMÁNYOK - A munkaerőpiac gazdasági-társadalmi kérdései}

2014-ben az alkalmazottak száma tekintetében 9,5\%-os növekedés volt megfigyelhető az előző évhez képest (országos szinten). Az összes IT alkalmazott 73\%-a Bukarestben (46\%), Kolozs (15\%), Temes (6\%) és Iasi megyékben (6\%) volt foglalkoztatva a vizsgálat időpontjában. Az ARIES 2017 kutatás alapján 2016-ban 1235 IT cég múködött Kolozsváron, amely 14036 főt foglalkoztatott, ez a Kolozsváron foglalkoztatott népesség 8,7\%-át jelentette (Tanulmány az IT piacról - Nemzeti öszszehasonlító vizsgálat 2017). Romániában, Kolozsváron a legmagasabb a foglalkoztatottakra jutó IT szakemberek száma, a 2014-es adatok alapján: minden 25 foglalkoztatottra jutott egy IT ágazatban dolgozó személy (Az IT ágazat Romániában: 14000 vállalattal, 75500 alkalmazottal és 4 milliárd euro bevétellel 2015), 2016ban már minden 11 foglalkoztatottból egy fő az IT ágazatban dolgozott (Tanulmány az IT piacról - Nemzeti összehasonlító vizsgálat 2017).

Az ágazati (IT) vállalatok számának, az éves üzleti forgalmuknak és a foglalkoztatottak számának vizsgálata alapján elmondható, hogy a főváros után Kolozsvár rendelkezik a legmagasabb értékekkel. Tehát, Kolozsvárnak a romániai IT piacon elfoglalt helye gazdaságilag fontos.

A kolozsvári IT piac sajátossága, hogy exportra dolgozik. Interjúalanyunk (BBTE, egyetemi adjunktus; kolozsvári IT cég projektmenedzsere, mentorprogram vezetője), aki képviseli a kolozsvári Babeş-Bolyai Tudományegyetemet és a privát szférát, így értékeli Kolozsvár helyzetét és kiszervezett tevékenységeit 2016-ban:

„(E)z most már nem csak bodyleasing-et jelent, vagy hangsúlyosan nem bodyleasing-et jelent. Ezeknek a projekteknek gyakorlatilag a teljes életciklusa, a legtöbb esetben itt van menedzselve, itt folyik ezeknek a tervezése, fejlesztése. Tehát itt egy kreatív tevékenység is folyik, a legtöbb esetben. Annyi a különbség, hogy maga a termék tulajdonos általában nem a helyi cég, nem a saját termékeket fejleszti." (BBTE, egyetemi adjunktus; kolozsvári IT cég projektmenedzsere, mentorprogram vezetője)

„(Ú)gy néz ki, ... már változóban van valamilyen szinten, tehát egyre több a kezdeményezés arra, hogy saját termékekkel próbáljanak meg piacra lépni a helyi cégek. És ez így volt rendjén. Kellett, ez az egész outsourcing múlt, ahhoz, hogy kialakuljon itt az az ökoszisztéma, az az infrastruktúra, és meglegyen az a tőkemennyiség, hogy el tudjunk kezdeni saját projektekben gondolkodni és ezt most már elég sok cég meg is lépi. Elég sok a start-up kezdeményezés is most már egyre inkább." (BBTE, egyetemi adjunktus; kolozsvári IT cég projektmenedzsere, mentorprogram vezetője)

A továbbiakban kihangsúlyozza, hogy szükség lenne külföldi angyalbefektetőkre, mivel a helyiek korlátozottabb finanszírozási lehetőségekkel rendelkeznek. 


\section{TEMATIKUS TANULMÁNYOK - A munkaerőpiac gazdasági-társadalmi kérdései}

Kolozsváron jelenleg az IT cégek között nagyon éles a verseny a munkaerőért, különösen a jó minőségű munkaerőért. Ez a jelenség, mint ahogy az elméleti részben bemutattuk globális. A versengés következtében a bérek növekedtek az ágazaton belül Kolozsváron, melyet különösen a nagyobb IT cégek és a nagy HR cégek befolyásolnak. Az interjúalanyok szerint a munkaerő Kolozsváron ma már drágábbnak számít, mint Indiában, Óceániában, Távol-Keleten, vagy Dél-Amerikában, azonban még mindig olcsóbb, mint Nyugat-Európában vagy Észak-Amerikában. Bár a munkabér megemelkedése felveti a külföldi tőke elvándorlásának esetleges veszélyét. Kolozsváron a vizsgálat pillanatában a munkabérek növekedése mellett az IT szektorban a külföldi tőke helyben maradása jellemző. A külföldi tőke helyben maradásának magyarázata meghaladja jelen tanulmány kereteit, az interjúalanyok szerint a munkabér mellett fontos a feladatok elvégzésének jó minősége is. A magyarázatok között még fontos szerepet játszhatnak a korábbiakban felsorolt állami foglalkoztatáspolitikai gyakorlatok (bér- és bérköltség-támogatás, valamint a személyi jövedelem-adó mentesség), amelyek csökkentik a munkaerővel kapcsolatos költségeket az ágazaton belül működő vállalatok esetében.

A kutatás helyválasztását Kolozsvár romániai IT piacon betöltött helye, valamint az IT szakember (felsőfokú) képzésben betöltött szerepe indokolta. Kolozsvár felsőoktatási helyzetének részletes bemutatására a következő fejezetben kerül sor. További kutatási helyszínek bevonására a rendelkezésre álló erőforrások korlátozottsága miatt jelen kutatás keretén belül sajnos nem volt lehetőség.

\section{Módszertan és kutatási eredmények}

Az egyetemek megkeresésénél az első kiválasztási szempont volt, hogy állami egyetemek legyenek, ugyanis a romániai felsőoktatásban résztvevők jellemzően állami felsőoktatási intézményekben tanulnak ${ }^{32}$. Az egyetemek kiválasztásánál második szempont volt, hogy a legnagyobb egyetemek kerüljenek be az esettanulmányba, ugyanis ezek azok a képzési intézmények, melyek a legmagasabb számban képzik az IT szakembereket az IT piacra, különösen a kolozsvári IT piacra. A kiválasztott egyetemek és karok a következők voltak: a Kolozsvári Műszaki Egyetem (KME) (Universitatea Tehnica din Cluj-Napoca) Automatika és Számítástechnika Kara (Facultatea deAutomatica si Calculatoare), valamint a kolozsvári Babeş-Bolyai Tudományegyetem (Universitatea Babes-Bolyai din Cluj-Napoca) Magyar Matematika és Informatika Intézete (Departamentul de Matematica si Informatica al Liniei Maghiare).

${ }^{32}$ A Tempo-Online adatbázis adatai alapján az Információs és kommunikációs technológiák (Technologiile informatiei si comunicatiilor) szakirányokon végzettek száma 2016-ban Kolozs megyében 1.045 fő volt, akik teljes mértékben az állami felsőoktatási intézményekhez tartoztak. Forrás: http://statistici. insse.ro:8077/tempo-online 


\section{TEMATIKUS TANULMÁNYOK - A munkaerőpiac gazdasági-társadalmi kérdései}

A tanulmány háttereként szolgáló feltáró kutatás keretén belül 2016 májusában a két legnagyobb kolozsvári állami egyetem képviselőjével készült fél-strukturált személyes interjú. Az interjúalanyok kiválasztásánál szempont volt, hogy az interjúalany aktív szerepet vállaljon az IT szakemberek felsőfokú képzésében, aki rendelkezik legalább tíz éves tapasztalattal ezen a téren, ismerje az adott felsőoktatási intézményen belül azokat a lehetőségeket és programokat, amelyek elősegítik a diákok átmenetét a felsőoktatásból az IT szektorba, ugyanakkor legyen rálátása az IT piac által a diákok kompetenciáival kapcsolatban megfogalmazott igényekre. Az első interjúalany a Kolozsvári Műszaki Egyetem Számítástechnika tanszékének egyetemi előadója (profesor), aki húszéves oktatási tapasztalattal rendelkezik, aki maga is ezen az egyetemen végezte tanulmányait a rendszerváltás előtt, ismeri az egyetem által nyújtott gyakornoki lehetőségeket, továbbá rálátással rendelkezik a cégek frissen végzettekkel kapcsolatos elvárásaira. A kutatás pillanatában az Automatika és Számítástechnika karon középvezetői tisztséget tölt be (2016), teljes munkaidőben foglalkoztatott az egyetemen. A második interjúalany a BBTE Magyar Matematika és Informatika Intézet (Departamentul de Matematica si Informatica al Liniei Maghiare) egyetemi adjunktusa „tizenéve” ${ }^{33}$ dolgozik az egyetemen. A kutatás pillanatában az egyetemen részmunkaidőben foglalkoztatott, szintén részmunkaidőben alkalmazott egyközepes méretű IT cégnél (alkalmazottszám tekintetében 70 alkalmazottal rendelkezik a cég), amely együttmüködésben a BBTE magyar informatika intézetével mentorprogramot ${ }^{34}$ múködtet. Az interjúalanyunk a mentorprogram felelőse. Ez az interjúalany összetettebb rálátással rendelkezik a frissen végzettek munkaerőpiaci átmenetére, annak köszönhetően, hogy mindkét szférában (akadémiai és piaci) aktív szerepet vállal négy éve, így ismeri a felsőoktatás által kínált lehetőségeket, valamint a piaci elvárásokat is.

\subsection{IT SZAKEMBERKÉPZÉS KOLOZSVÁRON A LEGNAGYOBB ÁLLAMI FELSŐOKTATÁSI INTÉZMÉNYEK PERSPEKTÍVÁJÁN KERESZTÜL}

\subsubsection{Képzési sajátosságok a vizsgált felsőoktatási intézményekben}

A két legnagyobb állami felsőoktatási intézmény Kolozsváron, ahol hagyománya van az informatika és számítástechnika oktatásnak a Kolozsvári Műszaki Egyetem (KME) és a kolozsvári Babeş-Bolyai Tudományegyetem (BBTE). A Kolozsvári Múszaki Egyetemen, a Számítástechnika és Automatizálás Karon belül múködő számítástechnika

\footnotetext{
${ }^{33}$ A doktori programot is beleszámítva.

${ }^{34}$ A mentorprogram a BBTE Magyar Matematika és Informatika Intézet és egy közepes méretű IT vállalat együttműködésében valósul meg, mely 2012-ben indult. A felsőoktatási programokról szóló fejezetben részletesen bemutatásra kerül a program.
} 


\section{TEMATIKUS TANULMÁNYOK - A munkaerőpiac gazdasági-társadalmi kérdései}

és automatizálás szakok mérnöki végzettséget nyújtanak, a képzés elvégzésére románul vagy angolul van lehetőség. A számítástechnika és automatizálás alapszakokra általában háromszoros a túljelentkezés az egyetemi képviselő szerint. A szakokra történő bekerülés feltétele a sikeres és jó eredménnyel záruló felvételi vizsga, amely véleménye szerint egy „elég nehéz matematikai teszt”-nek felel meg. A két szakon évente összesen 750 fó felvétele valósul meg, és az egyetemi képviselő szerint 70\% szerez diplomát. A diáklétszám az elmúlt három évtizedben tízszeres növekedést mutatott ('85-ben 60 diák végzett ezen a két szakon az egyetemi képviselő elmondása szerint, aki ezen az évfolyamon végzett abban az évben. A képzési struktúra a bolognai rendszerre való áttérés óta (2005-től) a következőképpen néz ki: 4 év alapképzés, melyet 2 év magiszteri képzéssel lehet folytatni. A korábbi öt éves képzés tananyaga koncentráltan kerül átadásra a négyéves képzés során, ugyanakkor az American Computer Machinery (ACM) rangos nemzetközi nonprofit intézmény programját alkalmazzák a tantárgyak összeállítása során. Az IT ágazatot dinamikus fejlődés jellemzi, ezért a tananyag is megköveteli a változtatásokat. Az egyetemi előadó a KME-n így fogalmaz:

„Hát, amit én tanultam ezelőtt 30 évvel és amit tanítok most... na, az nagy különbség." (KME, egyetemi előadó)

A négyéves alapképzéssel a végzősök jól boldogulnak a munkaerőpiacon, ezért a mesterképzést kevesebben választják (ezt a kérdést részletesen bemutatjuk az átmenet a felsőoktatásból a munkaerőpiacra című fejezetnél).

A kolozsvári Babeş-Bolyai Tudományegyetemen, a Matematika és Informatika Karon, az informatika szakirány elvégzésére négy nyelven van lehetőség román, angol, magyar és német nyelveken. Az Informatika szakra a 2018-as év folyamán 570 fó (2018. júliusi és szeptemberi felvételik - Végleges eredmények (alapképzés) 2018) nyert felvételt, amely az elmúlt 8 évben szintén jelentős növekedést mutatott. A 2010-es adatok (Felvételi vizsga (alapképzés), beiskolázási számok, visszaigazolások 2010) szerint 300 fó felvétele valósult meg a vonatkozó szakirányokon (informatika - informatica, és számítógép és információs technológiák - Calculatoare si Tehnologia Informatiei). A diákok felvételi vizsga alapján nyernek felvételt. A felvétel az informatika teszten elért eredmények függvényében történik: államilag támogatott vagy önköltséges helyre (2018. júliusi és szeptemberi felvételik - Végleges eredmények (alapképzés) 2018). A képzési struktúra a bolognai rendszerre való áttérés óta (2005) 3 éves alapozást jelent, melyet 2 éves szakosodás követ(het). Az informatika szak esetében a korábbi négyéves képzés tananyaga koncentráltan kerül átadásra a hároméves képzés során, ugyanakkor a képzés elmozdult gyakorlatibb irányba. Tíz éves távlatban nézve több a gyakorlati tárgyak száma az egyetemi képviselő elmondása szerint, annak érdekében, hogy minél jobb felkészültséget biz- 


\section{TEMATIKUS TANULMÁNYOK - A munkaerőpiac gazdasági-társadalmi kérdései}

tosítsanak a diákok számára. A magiszteri képzésre az egyetem képviselője szerint kisebb az érdeklődés, a magiszteri képzésen belül az elméleti szakokat kevesen választják, a gyakorlati szakokon túljelentkezés van, azonban, mivel a diákok 90\%-a dolgozik, ezért kevesebben fejezik be a mesterképzést.

\section{4,1,2. Az alapképzés célja}

Mindkét egyetem képviselője az alapképzés céljának az elméleti és gyakorlati tárgyak esetében is a megalapozást tartja a legfontosabbnak, amelyre a későbbiekben lehet építeni, akár a továbbtanulás révén, akár vállalati képzésekkel. A gyakorlati órákon (laboron) a technológiák használatának elsajátítása a cél a KME-n. Előfordul, hogy az egyetemet végzett hallgatók képzése kapcsán a vállalatok elvárásként fogalmazzák meg a végzősökkel szemben, hogy azonnal el tudják végezni a rájuk bízott feladatokat a projektekben, azaz rendelkezzenek a munkaadó profiljának megfelelő és az általa használt specifikus technológiák alkalmazásához szükséges ismeretekkel, azonban elmondása szerint, ennél fontosabbnak tartják a munkaadók is a megalapozást, egyrészt mert a technológia:
„[M]a van, holnap nincs. ... A cégek nem is annyira a technológiát igénylik, mert azt mondják, hogy gyorstalpalóval olyan 2-3 hónap alatt megtanítják a technológiát, amiben majd kell dolgozni a cégen belül. Inkább azt várják tő- lünk, hogy jó alapjai legyenek egy diáknak, amire aztán majd lehet építeni." (KME, egyetemi előadó)

A jelenlegi keretek között a lerövidült képzési idő miatt (3 év) a technológiák részletekbe menő oktatására nem lát lehetőséget a BBTE egyetemi adjunktusa sem.

A képzés második fontos célja az egyetemi oktatók szerint, hogy az oktatási intézmények az oktatás jó színvonalát meg tudják őrizni, és ennek következtében minden végzős találjon munkahelyet, jó munkahelyet és szakmában dolgozzon.

\subsubsection{Kihívások a felsőoktatásban}

A felsőoktatási intézmények oktatói rámutattak arra, hogy az IT piacon jelen levő szakember-hiány következtében a magán szféra javaslatot fogalmazott meg a legnagyobb felsőoktatási intézmények számára, amelyben az egyetemi képzésben részt vevők számának jelentős (másfélszeresére, duplájára) növelését, valamint más területekről történő átképzési programok elindítását szorgalmazta. Bár az egyetemeken az elmúlt évtizedben növekedett a diáklétszám, ez nem oldotta meg a piacon jelenlevő szakemberhiány problémát. A felsőoktatás fontos piaci szereplő a megfelelő 


\section{TEMATIKUS TANULMÁNYOK - A munkaerőpiac gazdasági-társadalmi kérdései}

szakember szám és minőség biztosításában, azonban a felsőoktatás is komoly kihívásokkal néz szembe. Az egyes kihívások felsorolása az egyetemi oktatók által felvetett témák alapján került be a kutatásba, fontossági sorrendben mutatjuk be az eredményeket, első helyen megjelölve azt a témakört (szakemberhiány), amely mindkét intézménnyel kapcsolatban megjelent, illetve amelyet a legrészletesebben kifejtettek. Az egyetemi oktatók az alábbi kihívásokat fogalmazták meg az oktatás színvonalának megőrzése érdekében, amelyekkel a vizsgált felsőoktatási intézményeknek szembe kell nézniük a kutatás pillanatában:

\subsubsection{Szakemberhiány}

Mindkét egyetemi oktató megfogalmazta, hogy az egyetemek komoly humánerőforrás problémákkal küzdenek. A KME Számítástechnika tanszékén az oktatói állások fele van betöltve az intézmény képviselője szerint. A BBTE informatika szakon is oktatóhiánnyal küzdenek, az oktatók közül egyre többen mennek át a privát szférába.

A felsőoktatási intézmények számára az oktatóhiány csökkentésére első számú megoldást jelenthetnének a frissen végzettek. Az oktatói pálya azonban nem jelent alternatívát a fiatalok számára az IT piaccal szemben, amely mögött több tényező húzódik meg, melyek szorosan összefonódnak. Az első befolyásoló tényező, hogy az akadémiai karrier feltétele a képzés folytatása (magiszteri és doktori képzés, doktori fokozat szerzése, kutatás). Az egyetemi oktatók tapasztalatai alapján alacsony az érdeklődés a magiszteri képzésre, ezt követően a doktori képzésre még alacsonyabb az érdeklődés, de ha valaki elvégzi a doktori képzést, az sem garancia, hogy ő a felsőoktatásban marad. A tanulmányok folytatása idő, energia, és anyagi ráfordítást igényel az egyik oldalon, a másik oldalon pedig jövedelemkiesést jelent. Az utóbbi átvezet a második befolyásoló tényezőre, amely a magas piaci kereslet az IT ágazatban. A releváns szakmai végzettséggel rendelkezőket a piac nagyon hamar felszívja. Mivel könnyen és/vagy gyorsan, valamint lényegesen jobb fizetéssel tudnak elhelyezkedni a frissen végzettek a piacon, mint a felsőoktatásban ${ }^{35}$ a KME oktatója felteszi a kérdést:

„[M]iért jönne hozzánk?” (KME, egyetemi előadó)

Tapasztalatai alapján, nehéz a frissen végzetteket, a jobb diákokat az oktatásban tartani, azt tapasztalja, hogy olyan esetben engedhetik meg maguknak ezt a karriert,

${ }^{35}$ Az állami szférában egy tanársegéd alig keresett valamivel többet a kutatás pillanatában (2016 májusában), mint a minimálbér (bruttó 1250 RON volt, ami br. 277 eurónak felelt meg), és az egyetemi adjunktus bére is alacsony volt. Ezzel szemben az IT szektorban két-háromszorosát is megkereshették az alkalmazottak pozíciótól függően. 


\section{TEMATIKUS TANULMÁNYOK - A munkaerőpiac gazdasági-társadalmi kérdései}

amennyiben a család támogatja (anyagilag is) a fiatalt, vagy a házastárs keresete magas. Ez a tendencia elmondásuk szerint 2007 után alakult ki.

A humán-erőforráshiányra három részmegoldást alkalmaztak a kutatás pillanatában a felsőoktatási intézmények. Az első megoldás, hogy vállalati szereplők bevonásával próbálták biztosítani a gyakorlati órák egy részét a felsőoktatásban (pl. a KME számítástechnika szak képviselője 80 főre becsüli az így bedolgozók számát, akik 4-6 órát tartanak). A BBTE képviselője megfogalmazta, hogy a külső szakemberek bevonása nehézségekbe ütközik, részben az akadémiai szférán belüli szabályozások és követelmények jelentősen leszúkítik az alkalmazotti jogviszonnyal bevonható szakemberek körét, pl. doktori programban való részvétel szükséges. Később az akadémiai előléptetésnek feltétele a doktorátus megszerzése, kutatói tevékenység ellátása, publikációk közlése elismert szakmai folyóiratokban. A második részmegoldás, hogy az oktatók egymás között felosztják, azon elméleti órák tartását, amelyre nem áll rendelkezésre humánerőforrás. Ez a gyakorlatban mindkét egyetemi oktató elmondása szerint azt jelenti, hogy a meglévő oktatók átlagban két oktató óraszámát viszik, mely elmondásuk szerint leterheli az oktatókat („,tanárok túlterhelve”, „le vagyunk terhelve”). A kutatás pillanatában mindkét egyetemen megjelentek az előzőekben bemutatott részmegoldások. A harmadik megoldás a BabeşBolyai Tudományegyetemen került említésre, ahol más szakterületekről vontak be szakembereket a gyakorlati tárgyak oktatásába. Ez a megoldás a minőség rovására is válhat, ugyanis azt a veszélyt hordozza magában, hogy a saját szakterületén jól felkészült oktató (más reál-szakokon) nem biztos, hogy jó felkészültséggel rendelkezik az újonnan bevont területen (informatika) is. A felsőoktatási intézmények oktatói leghangsúlyosabban az oktatóhiány problémáját emelték ki, az interjúalanyok maguk kezdeményezték a beszélgetést erről a problémáról, ez alátámasztja a jelenség fontosságát.

\subsubsection{Kutatástámogatás}

Az oktatás színvonalát, az oktatás mellett a kutatásokban való részvétel is befolyásolja. Romániában a felsőoktatási intézmények finanszírozása kvótarendszer és az egyetemek kutatási eredményei alapján történik. A KME oktatója szerint a kutatástámogatás a GDP <0,5\%-a, míg az Európa 2020 stratégia foglalkoztatási iránymutatása az öt kiemelt cél második javaslatában megfogalmazza az uniós GDP 3\%-ának kutatásra és fejlesztésre fordítását (Európai Bizottság - Európa 2020 stratégia 2015). 2006-2007-ben az egyetemi oktató szerint sok kutatási projekt finanszírozása futott a KME-n. A kutatási támogatások részben megoldást jelentettek a doktoranduszok és fiatal oktatók számára a jövedelem kiegészítésre. Az egyetem képviselője szerint, abban az időszakban a kutatási támogatás folyamatos volt, a gazdasági válság következtében azonban jelentősen lecsökkent (becslése szerint tizedére), amely a 2015/2016-os tanévben sem növekedett, továbbá kiszámíthatat- 


\section{TEMATIKUS TANULMÁNYOK - A munkaerőpiac gazdasági-társadalmi kérdései}

lanná vált, „nehéz bekerülni” a támogatottak közé. A KME keretén belül alternatív megoldást jelent a magántőke bevonása a kutatástámogatásba, mint például a Siemens vállalattal való együttmúködés, a projekt révén a doktoranduszok kutatási tevékenységét támogatták 3 éven keresztül. A KME oktatója ugyanakkor kihangsúlyozta a - egy közép- vagy hosszútávú együttműködés megvalósításával kapcsolatos - nehézségeket, amely egyrészt a cégek eltérő termékciklusából (6 hónap) adódik. Ennyi idő alatt kellene elkészíteni egy terméket (fejlesztést), a doktoranduszokat, azonban 3 teljes évig szükséges foglalkoztatni. Az oktató szerint ritkán adódik olyan téma, ami a doktoranduszok esetében lefed 3 teljes évet. A második nehézséget a projektindulásból adódó eltérések jelentik, míg a vállalat a gazdasági évhez igazodik, addig a kutatás az akadémiai tanév szerkezetét követi. Mindkét bemutatott kihíváshoz (szakemberhiányhoz és kutatástámogatáshoz) kapcsolódó nehézség, melyet mindkét egyetem képviselője megemlített, hogy az egyetem keretén belül a fizetéssel kapcsolatos lehetőségek limitáltak, ugyanakkor a fizetési szabályok szigorúak és nem veszik jó néven a kutatástámogatás ösztöndíj formában való felhasználását, amely járulékok megfizetésétől mentes jövedelem.

\subsubsection{Infrastruktúra}

A rendelkezésre álló infrastruktúra hiánya negatív hatással van az oktatás színvonalának alakulására. A KME esetében az infrastruktúra hiánya a rendelkezésre álló oktatói termek formájában nyilvánult meg. A képzés számára elérhető egyetemi infrastruktúra fejlesztésében (rendelkezésre álló termek számában) kisebb mértékű növekedés volt megfigyelhető, mint a diáklétszám változásban:

„[É]n is itt végeztem, ugyancsak számítástechnika szakot, mérnöki szakot. Akkor nem volt külön kar a számítástechnika és automatika. És ezen a két szakon - számítástechnika és automatika: 60 diák volt. Ez volt '85-ben.... Ma ugyancsak ezen a két szakon kb. 750-et veszünk fel évente. Tehát több mint tízszeresére nőtt meg a diákok száma és sajnos az épületek majdnem ugyanazok.” „[I]tt múködünk, ahol 30 évvel ezelőtt 60 diák végzett. Persze nagyon keveset nőttünk, de nem sokat, nem lényegeset. Most, ha igaz, kezdenek bele egy új építkezésbe, 8+1 emeletes épület." (KME, egyetemi előadó)

A bemutatott tényezők együttes figyelembevételével az oktatóhiány probléma fennmaradása, a kutatástámogatás alacsony mértéke, és a nem megfelelő infrastruktúra nem kedvez a nagymértékủ diáklétszám növelésnek, ugyanis nem biztosítottak az alapvető feltételek. 


\section{TEMATIKUS TANULMÁNYOK - A munkaerőpiac gazdasági-társadalmi kérdései}

\subsubsection{Megoldási javaslatok}

Az interjúalanyok a felsőoktatás (és a piac) humánerőforrás problémájának csökkentését, valamint a kiszervezett tevékenységekről a saját termékfejlesztés irányába történő elmozdulást hosszú távon két tényezőben látják megoldhatónak: egyrészt az akadémiai karrier vonzóvá tételében, az előbb bemutatott három tényező megoldása révén, másrészt új szakok indításában az IT szakkal határos tudományterületeken. A BBTE oktatója szerint az IT ágazatban a magánszféra konkrét hiány szakmákat jelölt meg, amelyre nehéz vagy nagyon nehéz találni szakembert, amelyek különösen a saját termékfejlesztéshez kapcsolódnak, például a user experience designer. Nincs ilyen jellegủ képzés elmondása szerint. A design szakhoz kapcsolódik, mely igényel ágazati ismereteket is. Ismernie kell, hogy technológiai szempontból mik az aktuális trendek, hogyan kell kinéznie egy divatos webes felületnek vagy mobilos felületnek, milyen szokásai vannak az Android-os és iOS felhasználóknak. Követni kell a változásokat. A BBTE egyetemi oktatója szerint nem az informatika oktatás feladata, inkább a designhoz kapcsolódik. A business analyst képzés a közgazdász képzéshez kapcsolódik meglátása szerint, ugyanakkor igényel ágazati ismereteket, akárcsak a sales-es pozíciókra történő felkészítés, ahol a szoftverprojektek jellemzőinek, az ágazat dinamikájának ismeretére van szükség. Hiányszakmaként említi meg a Quality Assurance (QA)-t, nagyon nehéz találni különösen mérnököket (QA engineer). Erre vonatkozóan sincs szakirányú képzés elmondása szerint, az informatika oktatás vagy átképzési programok tudnák ellátni ezt a feladatot. Itt nehezítő körülmény, hogy a szakmabeliek elóítélettel rendelkeznek a munkakörrel kapcsolatban, mivel a QA sokáig csak manuális tesztelést jelentett, és jelentős mértékben szakképzetlen munkaerőt vettek igénybe a cégek erre a munkára, a munkakör presztízse jelentős mértékben csorbult. A KME oktatója azt tapasztalta, hogy a villamosmérnöki végzettséggel rendelkező volt hallgatók jelentkeztek tesztelőnek (tester) IT cégekhez 2016-ban.

„[H]abár ők sokkal kevesebb informatikát tanulnak (...) csak jobbak, mint azok, akik nem végeznek semmit" (KME, egyetemi előadó)

Ebben a helyzetben jól felismerhető a munkaerőpiac belső szegmentálódásának a jelensége. A felsorolt hiányszakmák a saját termék kifejlesztésének folyamatához mind szükségesek, ezen a téren a felsőoktatásnak még alakulnia kell a piaci trendekhez, ahhoz, hogy a piac könnyebben elmozdulhasson a saját termékfejlesztés irányába az outsourcing tevékenységekről, a BBTE oktatója szerint.

A kolozsváriak körében is megjelenik a kiszervezés tevékenysége, mégpedig oda, ahol rendelkeznek a szükséges humánerőforrással: nyugatra (pl. Angliába) szervezik ki a userexperience design feladatokat a BBTE oktatója elmondása szerint, mely 


\section{TEMATIKUS TANULMÁNYOK - A munkaerőpiac gazdasági-társadalmi kérdései}

munkakör az elsődleges munkaerőpiachoz tartozik. Ebben a jelenségben tetten érhető a globalizáció hatásaként kialakult szegmentált munkaerőpiac, amelyet a nem szimmetrikus függési viszony jellemez, és ahol a centrum rendelkezik a magas képzettséget és specifikus képességeket igénylő humánerőforrással (mint a user experien cedesigner esetében), így a centrumba kerülnek kiszervezésre a (fél)perifériáról ${ }^{36}$ ezek a tevékenységek. Tehát a kiszervezés kétirányú a centrumból a perifériára, valamint a perifériáról a centrumba is megvalósul. A felsorolt hiányszakmák esetében az új képzések indítása más szakokon az egyetem keretén belül (design, közgazdaságtan, és ezen belül marketing, sales, gazdasági informatika szakterületeken ${ }^{37}$ ) jelentene részmegoldást, a Babeş-Bolyai Tudományegyetem oktatója szerint. Jelentős változás a humánerőforrás-problémák kezelésében (mind az IT piacon, mind a felsőoktatásban) szoros és jelentős külső és belső együttmúködéssel valósulhat meg: az iparági vállalatok, az állami szféra, és a felsőoktatási intézmények között, és ahogy rávilágított a BBTE oktatója, szükség van a felsőoktatási intézményeken belül a kapcsolódó tudományterületek bevonására is, mint: a design, marketing, sales és gazdasági informatika.

\section{2. ÁTMENET A FELSŐOKTATÁSBÓL A MUNKAERŐPIACRA}

Az IT szektorban a munkaerőért való versenynek köszönhetően egyelőre nem az a kérdés, hogy valaki el tud-e helyezkedni, hanem hogy hol és milyen munkakörben, milyen fizetéssel és juttatásokkal helyezkedik el? A KME egyetemi előadója úgy fogalmaz:

„[A] végzőseink nagy része (...) 110 százaléka alkalmazva van. (...) Ez azt jelenti, hogy nemcsak a végzősöket veszik fel, hanem már a harmad-, másod-, sőt az elsőéveseket is felveszik." (KME, egyetemi előadó)

Mindkét egyetem képviselője rávilágít a túl korai alkalmazás veszélyeire. A BBTE oktatója következményként említi a felsőoktatás elhagyását, ami a „túl nehéz, túl zsúfolt" alapképzési program és a rész- vagy teljes munkaidő összeegyeztetésének nehézségeiből fakad. Szerinte részmunkaidős állás mellett sem lehet mindkét feladatot jól elvégezni. A KME oktatója arra hívta fel a figyelmet, hogy az alapképzés ideje alatti alkalmazás jellemzően nem bizonyul jó stratégiának sem a cég, sem a diák számára:

${ }^{36}$ Ahol azon települések helyzetét értékeljük periférikusnak az országon belül, amelyek nincsenek, vagy alig vannak bekapcsolódva a globális piacba.

${ }^{37}$ A felsorolás nem teljeskörű, azonban az interjúalanyok ezeket a területeket nevezték meg. 


\section{TEMATIKUS TANULMÁNYOK - A munkaerőpiac gazdasági-társadalmi kérdései}

„Ez nem egy jó praxis, mivel a végén rájönnek, hogy nincsenek meg az alapok. Persze a diákok okosak, a legjobb reál szakos diákok hozzánk jönnek, tehát, nagyon hamar alkalmazkodnak a cégnél. Látszólag nem is kell az a 4 év, vagy 6 év képzés. Viszont akkor, amikor a cég változtat a profilon, amikor (...) nem csak egyszerű programozásról van szó, hanem ki kell gondolni egy terméket, annak az architektúráját, akkor meglátszik, hogy valakinek megvannak az alapjai vagy nem". (KME, egyetemi előadó)

Tehát, az alapok hiányában a végzettséggel nem rendelkező fiatal az új és egyre komplexebb feladatok elsajátításában korlátozottabb, ugyanakkor az általa betölthető pozíciók szintje is megrekedhet, vagy az előrehaladása lassabban következhet be a karrierútjában.

\subsubsection{Felsőoktatási programok}

A felsőoktatási intézmények a korábbiakban bemutatott oktatási tevékenység révén a képzés minőségének biztosítására törekednek, és elsősorban ezáltal segítik a fiatalok elhelyezkedését a munkaerőpiacon. Másodsorban, a képzés mellett a felsőoktatási intézmények különböző programokat dolgoztak ki annak érdekében, hogy a diákok megismerkedjenek a piaci lehetőségekkel és a számukra megfelelő döntést tudják meghozni az elhelyezkedés tekintetében.

A KME oktatója két típusú programot említ, melyek az egyetem keretén belül múködnek. Az első a gyakornoki programlehetőség a harmadéves hallgatóknak. Az egyetem összegyűjti a céges megkereséseket, melyekre a diákok utolsó év előtt (harmadév végén) jelentkezhetnek. 2016 tavaszi szemeszterében az egyetemnek 240 különböző céggel volt egyezsége, mellyel a diákok 90\%-ának tudtak gyakorlati helyet biztosítani. A bemutatkozó fórumon (pl. karriernap), az önéletrajz és interjú alapján, amennyiben egymásra talál a munkaadó és a gyakornok elvárása, úgy háromoldalú szerződést köt az egyetem, a diák és a munkaadó. A gyakornoki idő két- vagy három hónap, ez idő alatt az egyetem nemcsak a diákok elhelyezéséről gondoskodik, hanem ellenőrzi is a folyamat kimenetelét, például megszüntetik az együttműködést, amennyiben nem szakmai munka ellátására kérik a diákot a cégnél. Amennyiben a gyakornoki periódus beválik a diák és a munkaadó számára egyaránt, úgy az egyetem elvégzése után (vagy akár előbb) a diák alkalmazásba kerülhet a kipróbált cégnél. A második programtípusa karriernapok (2-3 nap), ahol a cégek bemutatkoznak és interjúszimulációkat végeznek a diákokkal (az egyetem képviselője nevetve fogalmazta meg előfordul, hogy az interjú csak nem szimuláció). Az egyetemi előadó kihangsúlyozza az előnyét ennek a programnak: 


\section{TEMATIKUS TANULMÁNYOK - A munkaerőpiac gazdasági-társadalmi kérdései}

„[N]agyon sokat segít, hogy a diákok megismerjék a cégeket. Nemcsak azt a céget, ahol ő dolgozik, hanem a szobatársa egy másik cégnél dolgozik, ő elmeséli, hogy ott mivel foglalkoznak (...) Úgyhogy mindenki megtalálja azt a munkahelyet, ahol jobban megfelel." (KME, egyetemi előadó)

A programok között még megtalálhatók az állásbörzék (jobshop), a rövid továbbképzések és üzleti ötletversenyek, mint a Hackathon ${ }^{38}$, végül a teadélutánok egy-egy cég képviselőjével (pl. Kávézás a Bosh-sal, La o cafeacu Bosch”).

A BBTE képviselője a magyar tagozat programlehetősége közül kiemelte a mentorprogramot, amely egy komplex program, mely egy közepes méretű (70 fős) kolozsvári magyar tulajdonban lévő, IT céggel együttműködésben került kidolgozásra. A cég sajátossága, hogy kizárólag magyarul is beszélő munkaerőt foglalkoztatott a vizsgálat időpontjában (2016-ban). A mentorprogram célja, hogy a diákok a cég által és a piacon alkalmazott eszközökkel és technológiákkal kapcsolatos ismeretekre szert tegyenek. A program 2012 óta múködik, évente tíz fővel indul, a program résztvevői a BBTE Magyar Matematika és Informatika Intézet Informatika szakos diákjai közül kerülnek ki. A programra négyszeres a túljelentkezés. A mentorprogram két és fél év hosszú képzés, mely az egyetemi képzésre épül, azzal összhangban van, és amelyre a képzés ideje alatt hétvégénként (1,5 nap) kerül sor. Három képzési modult tartalmaz, ezek egy-egy félévig tartanak és egymásra épülnek. A mentorprogram vezetője kettős szerepben van jelen ebben a programban, egyrészt az egyetem oktatója, másrészt az IT cég alkalmazottja. A diákok részvétele önkéntes, formális keretszerződés megkötése nélkül valósul meg, mely a mentorprogram koordinátorának kettős szerepének köszönhető, aki ismeri a diákokat oktatóként és a mentorprogramban végig kíséri őket. A mentorprogram keretén belül, a diákok olyan projekteket fejlesztenek, melyek nem hagyományos kliens projektek, és nem a haszonszerzés a célja, hanem amelyek speciális igényt elégítenek ki, és általában civil szervezeti megkeresésekre próbálnak reagálni. Másodév végén 2-3 hónapos nyári szakmai gyakorlatot hirdetnek (felvételi vizsga van a cég által alkalmazott technológiákból). A szakmai gyakorlat alatt a diákok napi 8 órában dolgoznak, kis csapatokban, ügyfél projekteken, bár nem hagyományos kliens projekteken, inkább speciális felkéréseknek (pl. civil szféra) tesznek eleget. Míg a program első része (képzés) nem jár a diákok számára pluszköltséggel vagy javadalmazással, addig a szakmai gyakorlat alatt ösztöndíjban részesülnek. Harmadéven a „Csoportos projekt” tantárgy keretén belül a diákok ezeket a projekteket tovább vihetik szakdolgozat témának vagy Tudományos Diákköri Konferenciákra. A mentorprogram részét képezi a (szak)dolgozat koordinálása is. A mentorprogram támogatást nyújt szakmai táborokban, konferencián való részvétel esetén is a legjobbaknak. A mentorprogram lejárta után a legjobb

\footnotetext{
${ }^{38}$ Lásd: http://kreativegyetem.sze.hu/mi-az-a-hackatlon
} 


\section{TEMATIKUS TANULMÁNYOK - A munkaerőpiac gazdasági-társadalmi kérdései}

diákokat meghívják a munkaközösségbe, azaz állást ajánlanak nekik (számuk évente változó 2-6 fó).

A BBTE oktatójának tudomása szerint elérhetők máshol is olyan programok melyek egy-egy elemét tartalmazzák az előbb bemutatott mentorprogramnak, véleménye szerint ilyen komplexitású program nem tipikus az egyetem(ek)en belül. A magyar tagozaton a programok között továbbá megtalálhatók a szakmai táborok és az előadássorozatok, melyek jó lehetőséget kínálnak a szakmai kapcsolatépítésre is. A román tagozat erősségeként a robotikával foglalkozó csoport tevékenységét hangsúlyozta a BBTE oktatója, akik hazai és külföldi versenyeken nagyobb intenzitással vesznek részt, mint a magyar tagozat diákjai. A magyar és román tagozatnak vannak közös programjai is, mint a szakmai gyakorlat és az állásbörzék.

A programok és az egyetemi képzés sikeressége kapcsán a BBTE oktatója megfogalmazta, hogy amennyiben a diákok részt vesznek a felsőoktatásban és az (alkalmazó) cégképzésén is, úgy megállják a helyük a munkaadók által támasztott követelményekkel szemben. Mindkét egyetem részéről álljon itt egy-egy példa:

„Külföldön is nagyon jól el tudnak helyezkedni és inkluzíve nagy cégeknél például olyan cégeknél, amelyek híresek arról, hogy nehéz bekerülni, mint például a Google -, vannak tanítványaink és jól helyt tudnak állni." (BBTE, egyetemi adjunktus; kolozsvári IT cég projektmenedzsere, mentorprogram vezetője)

„Épp a múlt héten találkoztunk egy igazgatóval, ez az ISDC-től. Diákunk volt. 2003-ban végzett, és most vezérigazgató, és kb. 300-an vannak. Nagyon gyorsan igazgató lett." (KME, egyetemi előadó)

\subsubsection{Munkaerőpiaci elvárások a felsőoktatási szereplők perspektíváján keresztül}

Az egyetemi oktatók a szakmai alapismeretek („átfogó kép a szakmáról”, „erős, stabil alaptudás”) mellett három készség csoportot jelöltek meg, melyek részben a „softskill"-ekre, másrészt az egész életen át tartó tanulás (, $\left.L L L L^{\prime}\right)$ fontosságára világítottak rá. Az első a csapatban való munkához szükséges készségeket tartalmazza: pl. kommunikáció, együttműködési készség, hozzáállás. A második készségcsoport a jó probléma-megoldási készséget tartalmazza (gondolkodásmód, felelősségvállalás, „hogyan old meg egy problémát?”). A harmadik készségcsoport a folyamatos tanulásra való nyitottságot tartalmazza, amely a technológia gyors fejlődésének (napirenden lenni az újdonságokkal), ugyanakkor annak köszönhető, hogy a szoftverfejlesztés más területek igényeinek kielégítését szolgálja, ezeket a területeket szükséges valamilyen szinten megismerni. A Word Economic Forum szerint 2020-ra a követke- 


\section{TEMATIKUS TANULMÁNYOK - A munkaerőpiac gazdasági-társadalmi kérdései}

ző kulcskompetenciák fogják meghatározni a munkaerőpiaci keresletet: komplex problémamegoldás, kritikus gondolkodás, kreativitás, irányító készség, koordináló készség, érzelmi intelligencia, ítélőképesség és döntéskészség, szolgáltatásorientáltság, tárgyalási készség, kognitív rugalmasság (Sebők 2018). Az interjúalanyok által megjelölt kulcskompetenciákat a vezetői készséggel és a kreativitással egészíti ki ez a felsorolás. Ez fogja jellemezni a globalizált piaccal rendelkező IT szektor munkaerőpiaci igényét az elkövetkező években.

\section{Összegzés}

A tanulmányban megvizsgáltuk, hogy melyek azok a tényezők, amelyek alakítják a felsőoktatásból az átmenetet a kolozsvári IT piacra az informatika, számítástechnika és automatizálás szakirányok friss végzősei esetében. A kérdés megválaszolása érdekében megvizsgáltuk, milyen kihívásokkal néznek szembe a piaci szereplők és a felsőoktatási intézmények, valamint, és milyen megoldási javaslatokat fogalmaztak meg a különböző gazdasági szereplők, a szűk keresztmetszet megtalálása érdekében.

A kutatási eredmények azt mutatják, hogy a Kolozsvári IT piac helyzete meghatározza a frissen végzettek átmenetét, melyet egyrészt a nyugati piactól való függés, másrészt a munkaerőért folytatott verseny jellemez. A kolozsvári IT piac elsősorban exportra dolgozik, kiszervezett tevékenységeket (outsourcing) végez. A megkérdezettek beszámoltak arról, hogy jelentős elmozdulás történt ebben a tekintetben az elmúlt két évtizedben. Az egyik oldalon, korábban a munkaerő-kölcsönzés (body leasing) volt jellemző, ma már a munkaerőt Kolozsváron foglalkoztatják. A másik oldalon a kiszervezett tevékenységeken belül a részfeladatok mellett, egyre gyakrabban jelenik meg a teljes projektciklus kiszervezése a kolozsvári vállalkozások számára a megkérdezettek szerint.

A függési viszonyt (második tényező) a hiányszakmák jelensége tartja fenn Kolozsváron. A függési viszony csökkentésére a megoldást az IT-vel határos szakterületeken új képzések elindításában látják az egyetemi oktatók. A függési viszonyban tetten érhető a globális IT piac szegmentáltsága, ahol Kolozsvár fél-periférikus helyen szerepel, a nyugati, centrum-országokhoz képest. Kolozsváron a hiányszakmákhoz kapcsolódó tevékenységeket a magas képzettségú és specifikus képességekkel rendelkező országokba és világvárosokba szervezik ki, például Kolozsvárról Londonba, a user experience designerhez kapcsolódó feladatokat. A helyi IT munkaerőpiac is szegmentált, melyre példa, hogy nehéz tesztelőket találni a szakképzettek között és más szakterületről jelentkezik erre a pozícióra a munkaerő (villamosmérnöki végzettséggel).

Második példa, hogy bizonyos cégek a diákok nagyon korai becsatornázására törekednek a munkaerőpiacon (első évtől elcsábítják), ahol az egyetemi végzettség és 


\section{TEMATIKUS TANULMÁNYOK - A munkaerőpiac gazdasági-társadalmi kérdései}

az alapkompetenciák nem jelennek meg elvárásként, és ahol a cég kisebb-nagyobb (2-12 hónap) képzési program révén tanítja be a munkavállalóit. A betanított feladatokat így el tudja látni a munkaerő, azonban jelentős váltás esetén, pl. a kreatív munkára való áttérés esetén, hamar plafonizálódhatnak a végzettséggel nem rendelkező munkavállalók lehetőségei a munkaerőpiacon, amely stagnálást eredményezhet, vagy egyfajta újrakezdést igényelhet a karrierúton.

A munkaerőért folytatott versenyt a munkaerőhiány problémájával összefüggésben vizsgáltuk meg. A kiélezett versenynek köszönhetően a frissen végzettek számára nem az a kérdés, hogy sikerül-e elhelyezkedni a piacon, hanem hogy hol, milyen munkakörben, milyen fizetéssel és juttatásokkal? A felsőoktatási intézmények a felsőoktatásban a képzés jó minőségének megőrzésére törekednek annak érdekében, hogy elősegítsék a frissen végzettek szakmában és megfelelő pozícióban történő elhelyezkedését. A felsőoktatási intézmények az alapképzés során a szakmai megalapozásra törekednek, amelyre a későbbiekben lehet építeni, akár a továbbtanulás révén, akár vállalati képzésekkel, továbbá a jó minőségű oktatás biztosítása a cél. A két felsőoktatási intézmény a képzés mellett szakmai programok által segítik a diákok minél jobb felkészülését a munkaerőpiacra. Mindkét egyetem esetében megjelennek a szakmai gyakorlatok, amelyek az előszobát jelentik az alkalmazás felé. A két, három hónapos gyakorlatot már elég hosszú időnek tartják ahhoz, hogy a munkaadó és a munkavállaló megismerje egymást és eldöntsék, hogy tudnak-e, szeretnének-e a továbbiakban együtt dolgozni. A rövid állásbörzék (2-3 nap) is jó alkalmat teremtenek a találkozásra, azonban nincs lehetőség megismerni a környezetet/munkaadót/munkavállalót. Ezek az ismeretek fontosak a döntéshozatalban, úgy a munkavállaló, mint a munkaadó szempontjából. Az interjúalanyok által említett legösszetettebb program a mentorprogram volt. Ez a program végigkíséri a diákokat csaknem a képzés teljes ideje alatt (2,5 év), mely négy pillért tartalmaz, köztük a képzést, a technológiák elsajátítását, kliens projektek megvalósítását (melynek nem profitszerzés a célja), a fizetett szakmai gyakorlatot, a szakdolgozat és TDK dolgozat koordinálását, valamint szakmai tábor és konferencia-támogatást. Ez az idő lehetővé teszi mindkét fél megismerését és kipróbálását. Az együttműködés a kiválasztottak esetében alkalmazással folytatódhat a program elvégzését követően a mentorprogramban résztvevő cégnél, amelynek felszívó ereje korlátozott. Más vállalatok részvétele a mentorprogramban szélesebb körben könnyítené meg a frissen végzettek átmenetét a felsőoktatásból a munkaerőpiacra.

A munkaerőhiány a piacon és a felsőoktatásban is érezteti hatását. A piac a munkaerőhiány problémájának leküzdése érdekében a kolozsvári felsőoktatáshoz fordult segítségért és a diáklétszám növelését, valamint átképzések indítását szorgalmazta, azonban a felsőoktatási intézmények a bemutatott feladatok ellátása közepette komoly kihívásokkal néznek szembe. Mindkét egyetem esetében megjelent az oktatóhiány, amely veszélyt jelenthet az oktatás minőségére nézve. A piac által kínál gyorsabb és magasabb jövedelem, a karrierlehetőségek, és az egyéb juttatások 


\section{TEMATIKUS TANULMÁNYOK - A munkaerőpiac gazdasági-társadalmi kérdései}

biztosítása miatt a frissen végzetteknek nem jelentett alternatívát az akadémiai pálya az elmúlt tíz évben. A probléma kezelése érdekében a felsőoktatási intézményekben három gyakorlat jelent meg: az első az intézményen belül más szakterületről érkező szakemberek bevonása (BBTE) volt, a második a külső szakemberek bevonása (BBTE és KME), míg a harmadik gyakorlat szerint a meglévő oktatók egymás között felosztották, az elméleti órák tartását, ennek következtében megnövekedett az oktatók leterheltsége (2-szeres óraszámmal dolgoztak). Az utóbbi megoldást egyik egyetemi oktató sem tartja hosszú távon fenntarthatónak. A második kihívást az alacsony kutatástámogatás jelentette, mely által kevesebb projekt valósult meg az elmúlt években, és ez negatívan hathat hosszú távon az oktatás színvonalára, a továbbtanulási kedvre, az egyetem megítélésére, a támogatások lehívásának mértékére és közvetett módon az innovációra. A harmadik kihívást az infrastruktúra hiánya (teremhiány a KME esetében) jelenti, mely szintén negatívan befolyásolhatja az oktatás színvonalát. Ennek a problémának a feloldására elindult egy kezdeményezés, mely egy új épület átadását célozza meg. Az egyetemi oktatók jelentős változást a humánerőforrás-problémák kezelésében (mind az IT piacon, mind a felsőoktatásban) szoros és jelentős külső és belső együttműködés révén látják megvalósíthatónak, az iparági vállalatok, az állami szféra, és a felsőoktatási intézmények között. Megfogalmazták, hogy a felsőoktatás (és a piac) humánerőforrás problémájának csökkentése, valamint a kiszervezett tevékenységekről a saját termékfejlesztés irányába történő elmozdulása hosszú távon: az akadémiai karrier vonzóvá tételével és az IT szakkal határos tudományterületeken új képzések indítása révén valósítható meg. Az utóbbi a hiányszakmák esetében jelentene megoldást, például a design, a közgazdaságtan, és ezen belül marketing, sales, gazdasági informatika szakterületek bevonása révén.

A végzettekkel kapcsolatos egyéni kulcskompetenciák vizsgálatában azt az eredményt kaptuk, hogy az egyetemi oktatók a munkaerőpiaci elhelyezkedésben fontosnak tartják a „softskill”-eket. A felsőoktatási intézmények oktatói a munkaerő-kulcskompetenciákkal kapcsolatban a szakmai kompetenciák mellett felhívták a figyelmet a „softskill”-ek fontosságára: jól tudjon csapatban dolgozni (együttmúködés, kommunikáció, hozzáállás) és jó problémamegoldó készséggel rendelkezzen; valamint az egész életen át tartó tanuláshoz kapcsolódó kompetencia szükségességére: nyitottság a folyamatos tanulásra. Az interjúalanyok által megjelölt kulcskompetenciákat a Word Economic Forum felsorolása a vezetői készségekkel és a kreativitással egészítette ki. Tehát, a munkaerőpiacon a jobb pozíciót, jobb karrierlehetőségeket, adott esetben magasabb jövedelmet nyújtó pozíciókban a fiatal munkaerőnek párhuzamosan több kulcskompetenciával szükséges rendelkeznie. 
www. metszetek.unideb.hu

\section{TEMATIKUS TANULMÁNYOK - A munkaerőpiac gazdasági-társadalmi kérdései}

\section{Irodalom}

797/2012 sz. Kormány Határozat, 2012 a nagyvállalatok támogatásáról - Hotararea Guvernului Nr. 797/2012 http://codfiscal.net/25189/hg-7972012-schema-deajutor-de-stat-pentru-sprijinirea-investitiilor, Letöltés időpontja: 2015. szeptember 03.

335/2013. számú törvény a felsőfokú végzettséggel rendelkezők gyakornoki idejének eltöltéséről, 2013 www.anofm.ro/files/LEGEA\%20Nr.335.pdf, Letöltés időpontja: 2015. szeptember 03.

76/2002. számú törvény a munkanélküli biztosításról és a munkaerő ösztönzéséről, a 2014-es módosítással www.ajofmbn.ro/documente/legislatie/Legea\%20 nr.\%20762002\%20privind\%20sistemul\%20asigurarilor\%20pentru\%20somaj. pdf, Letöltés időpontja: 2015. szeptember 03.

217/4172/1348/835/2015. számú Rendelet - a jövedelemadó megfizetésének kötelezettsége alóli mentességről, 2015 http://lege5.ro/Gratuit/g4ztsmrugu/ordinul-nr-217-4172-1348-835-2015-privind-incadrarea-in-activitatea-de-creatiede-programe-pentru-calculator, Letöltés időpontja: 2015. szeptember 03.

79/2017. számú a Románia Kormánya által kiadott sürgősségi kormányrendelet a Nemzeti Pénzügyi Intézet (Agentia Nationala de Administrare Fiscala) honlapján, mely a 227/2015 számú törvény módosításait és kiegészítését tartalmazza a személyi jövedelemadó mértékére vonatkozóan, 2017 https://static.anaf.ro/ static/10/Anaf/legislatie/OUG_79_2017.pdf

ARIES Transilvania honlapja, 2016 http://aries-transilvania.ro

ARIES Transilvania 2015 kutatási eredmények az Európai Uniós politikák hírportálján:

Az IT ágazat Romániában: 14.000 vállalattal, 75.500 alkalmazottal és 4 milliárd euro bevétellel-Industria IT din România: 14.000 de companii, 75.500 de angajaţi și venituri totale de $4 \mathrm{mld}$. euro http://www.euractiv.ro/economic/industria-it-dinromania-14.000-de-companii-75.500-de-angajati-si-venituri-totale-de-4-mld.euro-2722

ARIES Transilvania 2017 kutatási eredmények:

Tanulmány az IT piacról - Nemzeti összehasonlító vizsgálat-Studiul Pietei de IT - Analiza ComparativaNationala https://itech.aries-transilvania.ro/studiul-pietei-de- it-analiza-comparativa-nationala/

Az IT piac vizsgálata 2017 - StudiulPietei de IT2017 https://www.itstudy.ro/

Cabinet expert - szakmai könyvelői online fórum, 2015 www.cabinetexpert.ro/ 2015-01-09/important-coeficientii-pentru-indexare-salariu-minim-2015nu-se-mai-aplica-studii-superioare-etc.html 


\section{TEMATIKUS TANULMÁNYOK - A munkaerőpiac gazdasági-társadalmi kérdései}

Civil szervezeti hírportál - Friedrich-Ebert-Stiftung Romania monitor Social projekt infografikák, 2017 https://www.stiri.ong/ong/sub-lupa/it-sau-agriculturacum-arata-cele-doua-industrii-in-pib-si-numar-de-angajati

Csata, Zs. (2017): Munkaerốpiaci egyenlőtlenségek Romániában, etnikai metszetben. Erdélyi Társadalom, 2017/1, 81-103.

Digi24 hírportál honlapja:

A román állam fedezi az IT ágazatban dolgozók fizetését. Egy jászvásári (Iasi) vállalat 5,4 millió euro támogatást kap az államtól-Salariile angajatilor IT, platite de stat. O companie din Iasi va primi 5,4 milioane de euro de la buget www.digi24.ro/ Stiri/Regional/Digi24+Iasi/Stiri/Salariile+angajatilor+IT+platite+de+stat+O+companie+din+Iasi+va+

Európai Bizottság honlapja:

Európai Foglalkoztatási Stratégia - European Employment Strategy www.ec.europa.eu/employmentstrategy Letöltés időpontja: 2016. június 16.

Európa 2020 stratégia https://ec.europa.eu/info/business-economy-euro/economic-and-fiscal-policy-coordination/eu-economic-governance-monitoring-prevention-correction/european-semester/framework/europe-2020-strategy_hu Letöltés időpontja: 2018. szeptember 03.

Youth Guarantee programról, 2018 https://ec.europa.eu/social/main.jsp?catld= 1079

Népszámlálási adatok adatbázisa - CensusHub www.ec.europa.eu Letöltés: 2016. január 15.

Eurostat adatok www.ec.europa.eu Letöltés: 2016. január 15.

Európai Uniós politikák hírportálja, 2015 www.euractiv.ro/fonduri-ue-programeale-comisiei-europene/Garantia-pentru-tineri-lansata-oficial.-Subventii-consistente-pentru-angajatori-si-start-up-385

Goleman, D. (1997): Érzelmi intelligencia. Háttér Kiadó, Budapest.

Goleman, D. (2008): Társas intelligencia. Az emberi kapcsolatok új tudománya. Nyitott Könyvmühely Kiadó, Budapest

Granovetter, M. (1973): The Strength of Weak Ties. American Journal of Sociology. Vol. 78. No 6. pp: 1360-1380

Granovetter, M. (1992): Economic Action and Social Structure. The Problem of Embeddedness. In: Mark Granovetter - Richard Swedberg (szerk.): The Sociology of Economic Life, Boulder, CO: Westview Press.

Granovetter, M. (1995): Afterword 1994: Reconsiderations and a New Agenda. In: Portes: Getting a Job, 2. kiadás, Chicago, IL, University of Chicago Press. 


\section{TEMATIKUS TANULMÁNYOK - A munkaerőpiac gazdasági-társadalmi kérdései}

Ifjúsági Garancia megvalósítási terv: Romániai program honlapja, 2016 http://garantiapentrutineret.ro

Ifjúsági Garancia megvalósítási terv: Magyarországi program honlapja, 2018 http:// ifjusagigarancia.gov.hu

IT Bridge - online magyarországi hírportál http://it-bridge.hu/print/Fooldal/it_ bridge/School/Erdelyi_Szilicium-volgy.html

IT Oursourcing News on Central and Eastern Europe - online nemzetközi hírportál http://itonews.eu/cluj-napoca-transylvania-the-heart-of-romanian-softwaredevelopment/

Kiss, D. - Péter, L. (2018): Analiza mediului antreprenorial vizând sectoarele IT și industriile creative în regiunea Nord-Vest. Kézirat.

Kolozsvári Babes-Bolyai Tudományegyetem Matematika és Informatika Kar honlapja - felvételivel kapcsolatos adatok: 2018. júliusi felvételi - Végleges eredmények (alapképzés) - Rezultatele finale ale concursului de admitere, nivel licenta, sesiuneaiulie $2018 \mathrm{http} / / / \mathrm{www} . c s . u b b c l u j . r o / r e z u l t a t e l e-f i n a l e-a l e-c o n c u r s u l u i-d e-a d-$ mitere-nivel-licenta-sesiunea-iulie-2018/ Letöltés: 2018. november 25.

2018. szeptemberi felvételi - Végleges eredmények (alapképzés) - Rezultatele finale ale concursului de admitere, nivel licenta, sesiuneaseptembrie $2018 \mathrm{http} / / \mathrm{www}$. cs.ubbcluj.ro/rezultatele-finale-ale-concursului-de-admitere-nivel-licenta-sesiunea-septembrie-2018/ Letöltés: 2018. november 25.

Felvételi vizsga (alapképzés) beiskolázási számok, visszaigazolások 2010 - Validareaconcursului de admitere 2010 https://www.yumpu.com/it/document/ view/50212633/forma-de-invatamant-zi-licenta-admitere-universitatea-babes-bolyai Letöltés: 2018. november 25 .

Mennyibe kerül Kolozsvár? - Catcosta Clujul? http://catcostaclujul.ro/cum-se-impart-it-istii-clujeni-pe-companii-top-20-la-1-ianuarie-2016/

Nemzeti Statisztikai Hivatal:

Tempo-Online adatbázis: http://statistici.insse.ro:8077/tempo-online/\#/pages/ tables/insse-table Letöltés: 2018. november 29.

eDemos adatbázis és a háztartásokra vonatkozó AMIGO munkaerő-felmérés adatai: www.insse.ro Letöltés: 2018. november 29.

Nemzetközi Munkaügyi Szervezet - International Labour Organization honlapja: Key Indicators of The Labour Market adatbázis (KILM) és a European Labour Force Survey adatbázisa www.ilo.org Letöltés: 2016. január 15.

Piore, M. (1972): Notes for Theory of Labor Market Stratification, Working Paper No. 95, Massachusetts Institute of Technology. Dept. of Economics.

Póczik, Sz. - Dunavölgyi, Sz. (szerk.) (2008): Nemzetközi migráció - nemzetközi kockázatok. Budapest, HVG-ORAC Lap- és Könyvkiadó Kft. 
www. metszetek.unideb.hu

\section{TEMATIKUS TANULMÁNYOK - A munkaerőpiac gazdasági-társadalmi kérdései}

Polányi, K. (1992): The Economy as Instituted Process. In: Mark Granovetter - Richard Swedberg (szerk.): The Sociology of Economic Life. Boulder, CO, Westview Press. 29-51.

Portes, A. (1998): Socialcapital: itsorigins and applications in modern sociology. Annual Review of Sociology 22, 1-24

Portes, A. (2010): Economic Sociology: A Systematic Inquiry. Princeton, Princeton U.P. 1-69.

Putnam, R. D. (1995): Bowling Alone. The Collapse and Revival of American Community. New York, I. fejezet. Forrás: http://www.nytimes.com/books/first/p/putnam-alone.html. Letöltés ideje: 2012. november 5.

Putnam, R. D. (2000): Bowling alone. New York, Simon and Schuster.

Romániai Munkaügyi és Szociális Igazságosság Minisztérium honlapja - Ministerul Muncii si Justitiei Sociale: Sajtótájékoztató: „Ifjúsági Garancia” a legkiterjedtebb program a fiatal munkanélküliség visszaszorítására az elmúlt 25 évben- "Garantia pentru Tineret", cel mai amplu program de combatere a somajuluiin randul tinerilor, din ultimii 25 ani http://www.mmuncii.ro/j33/index.php/ro/comunicare/comunicate-de-presa/3765-garantia-pentru-tineret-cel-mai-amplu-program-de-combatere-a-somajului-in-randul-tinerilor-din-ultimii-25-ani-8-aprilie-2015

Nemzeti Foglalkoztatási Stratégiáról, 2014 - Strategia Nationala pentru Ocuparea Fortei de Munca www.mmuncii.ro/j33/images/Documente/Munca/2014-DOES/ 2014-01-31_Anexa1_Strategia_de_Ocupare.pdf Letöltés időpontja: 2015. szeptember 3.

Románia TV hírportálja www.romaniatv.net/proiectul-primul-loc-de-munca-a-trecut-de-senat--ce-facilitati-primesc-angajatorii_248857.html

Román Kormány honlapja: cikk a minimálbérről, 2016 http://gov.ro/ro/guvernul/ sedinte-guvern/salariul-de-baza-minim-brut-pe-tara-majorat-incepand-cu-1mai-2016

Román Nemzeti Bank árfolyam archívum http://cursbnr.clubafaceri.ro/arhiva/

Sebők, M. (szerk.) (2018): A munka világa a 21. század elején. Foglalkoztatáspolitikai és munkaerőpiaci kézikönyv. Saxum Kiadó, Budapest.

Szabó, K. (1998): Kihelyezési hullám. A piac térhódítása a vállalati hierarchiák rovására. Közgazdasági Szemle, XLV, évf. 137-153.

Szentes, T. (2002):A globalizációs folyamat kedvező és kedvezôtlen hatásai. Magyar Tudomány. (47) 6. sz. 708-719. 
www. metszetek.unideb.hu

\section{TEMATIKUS TANULMÁNYOK - A munkaerőpiac gazdasági-társadalmi kérdései}

Támogatási lehetőségek online hírportálja www.finantare.ro/salariile-angajatilorit-platite-de-stat-o-companie-din-iasi-va-primi-54-milioane-de-euro-de-la-buget.html

Transindex.ro - erdélyi magyar hírportál, 2013, 2015.

Forrás 1: www.penzcsinalok.transindex.ro/lokalis/20130225-kolozsvar-viragzik-az-it-szektor-meg-vegtelen-szamu-vegzost-elbirna

Forrás 2: http://penzcsinalok.transindex.ro/lokalis/20131202-valsag-fenyegeti-a-kolozsvari-it-szektort

Forrás 3: http://penzcsinalok.transindex.ro/lokalis/20150916-van-e-eleg-jokocka-avagy-mitol-van-szakemberhiany-a-hazai-it-szektorban

Veres, V. (2013): Népszámlálás 2011: A népességszám, foglalkozásszerkezet és iskolázottság nemzetiség szerinti megoszlása Romániában. Erdélyi Társadalom, 2013/2, 23-54.

Wallerstein, I. (2010): Bevezetés a világrendszer-elméletbe. L'Harmattan - Eszmélet Alapítvány, Budapest.

Ziarul Financiar - pénzügyi napilap online felülete:

Interjúrészletet Oana Botolan Datkival, a South East Europe vállalat, Consulteam humánerőforrással foglalkozó csoportjának képviselőjével, 2015 www.zf.ro/zf24/ce-salariu-primeste-un-absolvent-de-facultate-la-primul-job-14632761 